\title{
PEMROGRAMAN SISTEM PENGAMAN RUMAH OTOMATIS YANG TERHUBUNG DENGAN TELEPON SELULER BERBASIS MIKROKONTROLER ATMEGA8 DAN ATMEGA162
}

\author{
Donny Pratama, Subali \\ Program Studi Diploma III Teknik Elektro \\ Fakultas Teknik Universitas Diponegoro
}

\begin{abstract}
Donny Pratama, Subali, in paper programming of auto home security system connected to mobile phone based on microcontroller ATMEGA8 and ATMEGA162 explain that in modernization era, almost all using automation tools, both in industrial, office, especially at home. Especially with the advance of age more unemployment also exist. With so many unemployed crime was more rampant. Therefore, the security of the home and its contents is very necessary for every homeowner. Especially when the house in a discharged condition or homeowners are doing activities outside the home. Home security system that uses a microcontroller-based mobile phone as a medium of information is a tool that is needed in every home. Where this system in any room in the home will attach several sensors are used to monitor the condition of the house. The sensors used include PIR sensor (Passive Infra - Red) to detect motion, gas sensors to detect a gas leak and also uses a temperature sensor to determine the temperature of the room. All these sensors are programmed according to the function of each tool. And as a basic programming language used compiler (Bascom) to support the work of all the sensors. For sensor work will then be processed by a microcontroller which will then be sent the information to a cell phone via a modem homeowners.
\end{abstract}

Keyword : home security systems, mobile telephone, microcontroller, ATMEGA8, ATMega162

\section{PENDAHULUAN \\ Latar Belakang}

Perkembangan teknologi di bidang elektronika sangat cepat setelah ditemukan piranti semikonduktor sebagai komponen aktif, apalgi setelah adanya teknologi mikroprosessor dan mikrokontroler. Dengan peralatan tersebut dapat dibuat berbagai alat yang dapat membantu manusia dalam menyelesaikan berbagai macam kesulitan dan permasalahan. Dengan menggunakan teknologi mikroprosesor dan mikrokontroler dapat dibuat dengan berbagai macam peralatan elektronika yang dapat memberikan kemudahan dan kenyamanan bagi manusia dalam melaksanakan tugas dan pekerjaannya.

Salah satu alat yang dapat dibuat berbasis mikrokontroler yaitu suatu sistem pengaman rumah otomatis yang dikontrol melalui telepon seluler. Di zaman perkembangan teknologi seperti sekarang ini, dimungkinkan sekali untuk membuat suatu alat yang dapat digunakan sebagai pengaman, baik yang terdapat di rumah, perkantoran, ruko, mal, maupun apartemen dengan sebuah pengendali jarak jauh berupa telepon seluler. Penulis merencanakan suatu sistem pengaman, dimana pengendalian tersebut memadukan perangkat lunak dan perangkat keras. Pada perencanaan penulis menggunakan mikrokontroler sebagai alat kendali perangkat keras yaitu mikrokontroler tipe ATMega8 dan tipe ATMega162. Bahasa pemrograman Basic Compiler sebagai perangkat lunak program aplikasi.

\section{Pembatasan Masalah}

Agar dalam pembahasan masalah tidak keluar dari pokok persoalan, penulis membatasi pembahasan hanya pada :

- Sistem pengaman rumah otomatis yang berbasis mikrokontroler Atmega8 dan ATmega162 dengan pemograman Basic Compiler.

- Komunikasi antara mikrokontroler dalam pengolahan data.

- Fungsi pemrograman pada sensor, mikrokontroler, dan komponen penunjang lain.

- Downloader sebagai media penginput data ke mikrokontroler.

\section{LANDASAN TEORI \\ Pemrograman}

Pemrograman adalah proses menulis, menguji, memperbaiki (debug), dan memelihara kode yang membangun sebuah program komputer. Di dalam pemrograman kode ditulis dalam berbagai bahasa pemrograman

\section{Pemrograman Bascom Avr}

BASCOM-AVR adalah salah satu peralatan untuk pengembangan / pembuatan program yang kemudian ditanamkan dan dijalankan pada mikrokontroller untuk mikrokontroller keluarga AVR (Alf and Vegard's Risc processor). BASCOM-AVR juga bisa disebut sebagai IDE (Integrated Development Environment) yaitu lingkungan kerja yang terintegrasi, karena 
disamping tugas utamanya (meng-compile kode program menjadi file HEX / bahasa mesin). Selain itu BASCOM-AVR juga memiliki kemampuan / fitur lain yang berguna sekali, contoh :

- Terminal yaitu untuk monitoring komunikasi serial.

- Programmer yaitu untuk menanamkan program yang sudah di-compile ke mikrokontroller.

Berdasarkan namanya pemrograman BASCOM (Basic Compiler) merupakan bahasa yang masih termasuk dalam bahasa pemrograman BASIC. Untuk mempelajari bahasa BASCOM ini tidak jauh berbeda dengan bahasa BASIC (Visual Basic, Turbo Basic, dll). Struktur pemrogramannya juga tidak ada perbedaan hanya perlu lebih mendalami dan mempelajari bahasa pemrograman BASCOM ini saja.

\section{Mikrokontroler ATmega8}

Mikrokontroler AVR keluaran dari atmel terbagi menjadi tigakelompok yaitu: AT90S, ATTiny, dan ATMega. Yang penulis pakai disini adalah termasuk dalam kelompok ATMega, dengan seri ATmega8 pada gambar 2.9.

\section{Mikrokontroler ATmega162}

ATMEGA162 memiliki bagian sebagai berikut : Saluran I/O sebanyak 35 buah (PortA, Port
B, Port C, Port D, dan Port E), memiliki dua buah 8-bit Timer/Counter Dengan Separates Prescalers dan Compare Modes ,memiliki dua buah 16-bit Timer/Counter Dengan Separates Prescalers,Compare Modes,Dan Capture Modes. Selain itu mikro ini juga memiliki CPU yang terdiri atas 32 buah register,Watchdog Timer dengan osilator internal, SRAM sebesar $1 \mathrm{k}$ byte, memori Flash sebesar 16k byte dengan kemampuan Read While Write, unit interupsi internal dan eksternal, Port antarmuka SPI, EEPROM (Electrically Erasable Programmable Read Only Memory) sebesar 512 byte yang dapat diprogram saat operasi, antarmuka komparator analog, dan Port USART untuk komunikasi serial

\section{PRINSIP KERJA SISTEM}

Gambar blok diagram sistem serta diagram alir dari sistem ini ditunjukkan pada Gambar 1, 2 dan 3. Gambar 1 merupakan diagram blok sistem. Gambar 2 merupakan diagram alir operasi sistem pada mikrokontroler ATMEGA8 sedangkan gambar 3 merupakan diagram alir operasi sistem pada mikrokontroler ATMEGA162.

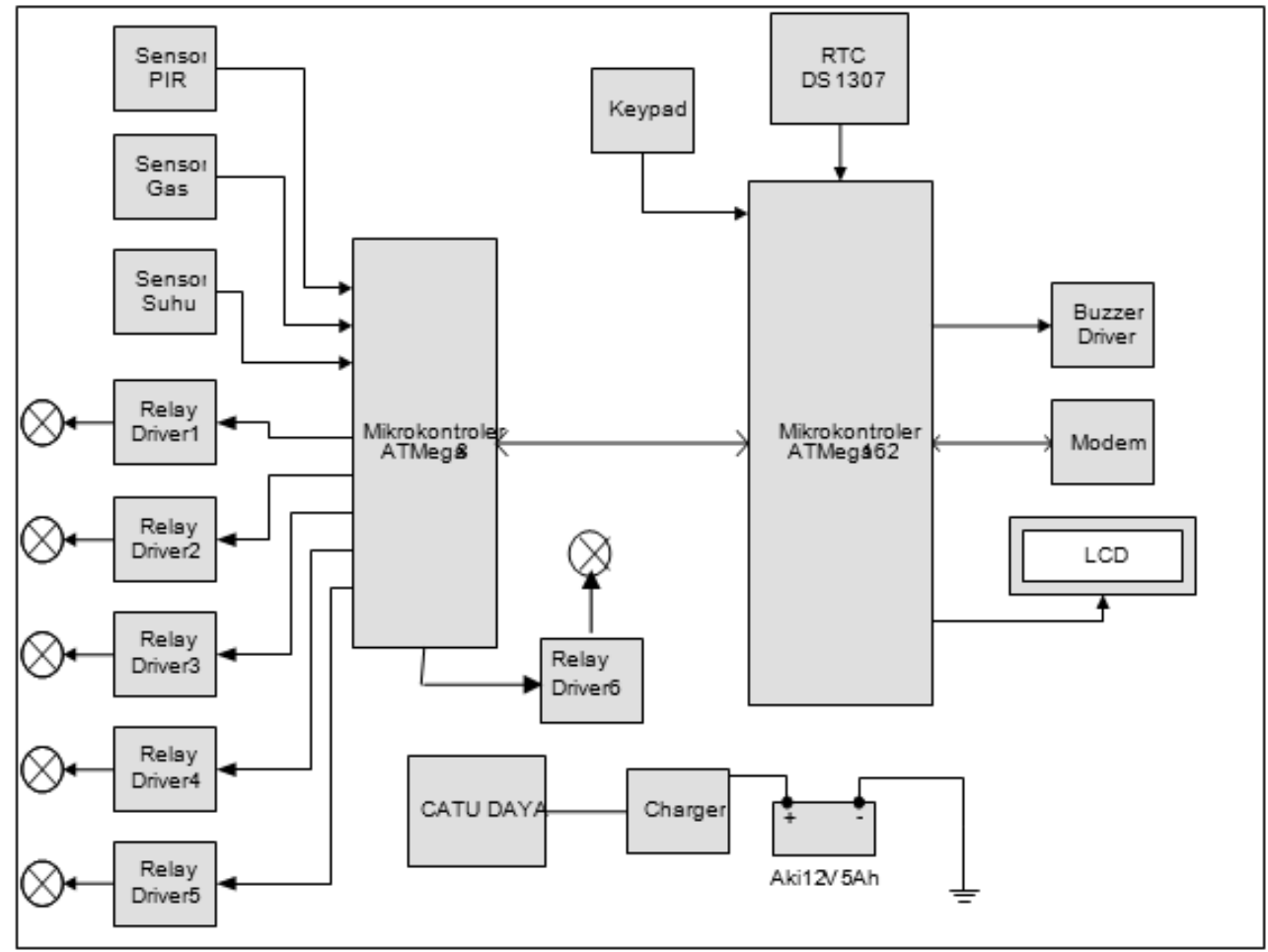

Gambar 1. Blok Diagram Sistem 


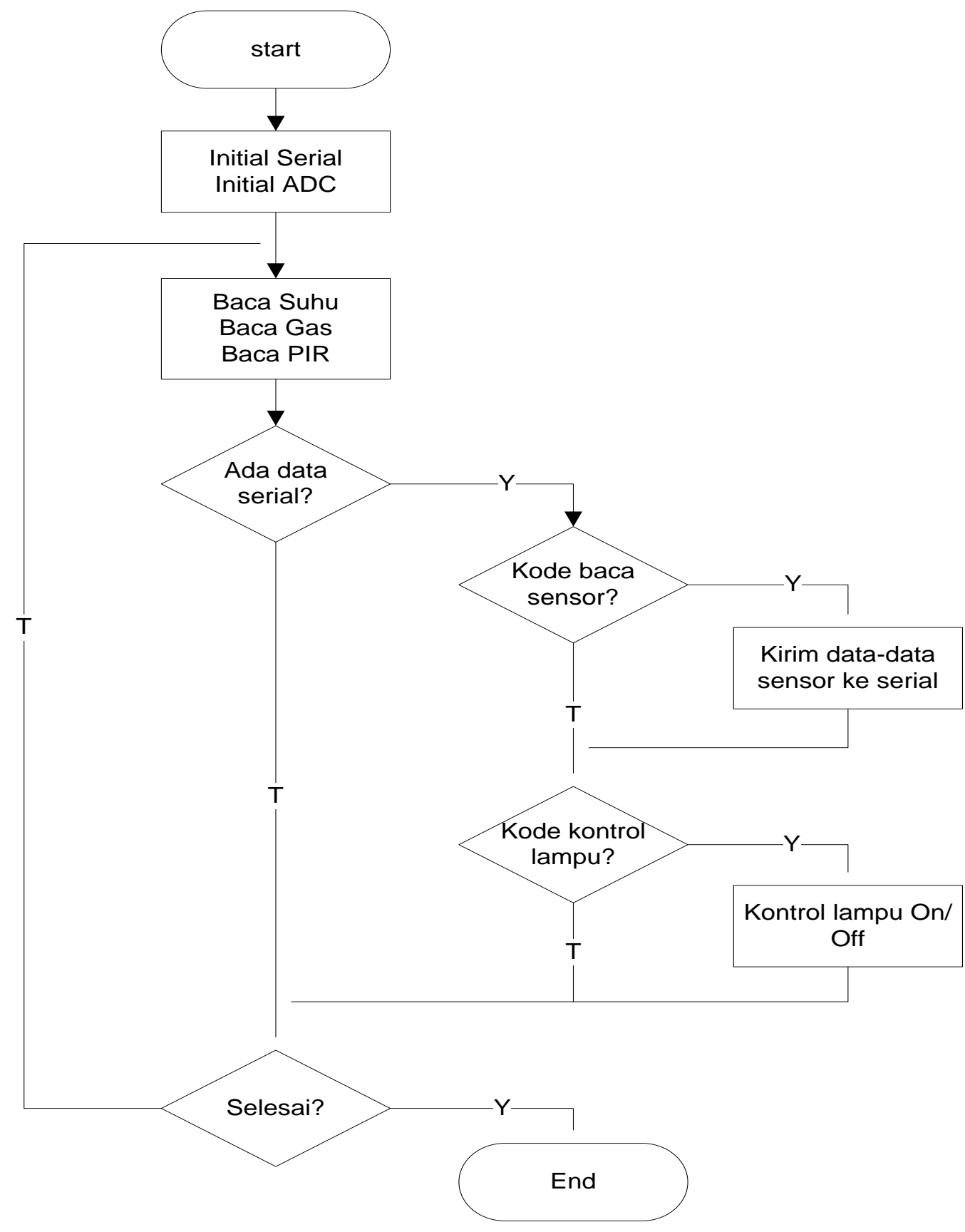

Gambar 2. Flowchart Pemrograman mikrokontroler ATmega8 


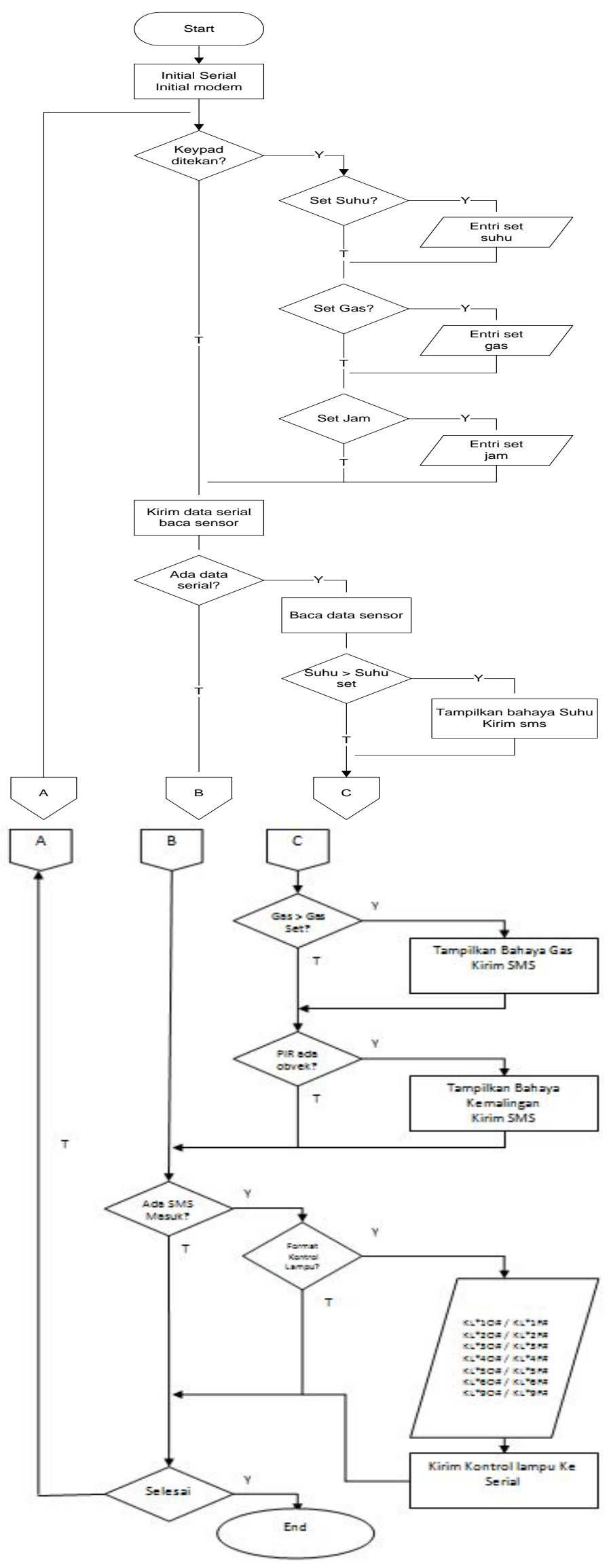

Gambar 3. Flowchart Pemrograman mikrokontroler ATmega162 


\section{PEMBUATAN PROGRAM}

\section{Proses Pembuatan Program}

Perangkat lunak yang digunakan pada tugas akhir ini dibuat menggunakan pemrograman basic compiler / BASCOM AVR produksi dari MCS Electronics. Pemrograman BASCOM AVR ini merupakan bahasa tingkat tinggi yang mudah dipahami bagi pemula. BASCOM AVR merupakan pemrograman yang sering digunakan untuk melakukan pemrograman mikrokontroler ATMega atau AVR. Sistem untuk BASCOM AVR cukup handal karena dapat berjalan dibawah sistem operasi windows.

Dalam pembuatan tugas akhir ini penggunaan perangkat lunak sangat penting, mengingat perangkat lunak digunakan untuk pengaturan keseluruhan kerja sistem, baik perangkat keras maupun perangkat keras itu sendiri. Langkah-langkah pembuatan program tersebut sebagai berikut :

- Membuat diagram alir (flowchart) dari program yang akan dibuat.

- Membuat program menggunakan pemrograman basic compiler dengan referensi diagram alir.

- Mengkompilasi program yang telah dibuat sampai tidak terjadi kesalahan.

- Pengisian program.

\section{Pembuatan Diagram Alir}

Dalam menyusun diagram alir diusahakan dapat membagi proses yang kompleks menjadi sub program yang lebih kecil, sehingga pencarian kesalahan akan lebih mudah. Selain itu akan memudahkan orang lain dalam membaca alir program yang dibuat. Untuk diagram alir yang dibuat juga harus saling berhubungan antara dua mikrokontroler yang dibuat. Karena disini memakai dua mikrokontroler sehingga diagram alir (flowchart) yang dibuat juga untuk mirkokontroler ATMega8 dan mikrokontroler ATMega162.

\section{Perencanaan Program}

Penulisan program dilaksanakan setelah diagram alir selesai dirancang. Pemilihan editor teks disesuaikan dengan kebiasaan dan kesenangan. Agar teks yang telah dibuat nantinya dapat dimengerti oleh program basic compiler, maka hasil penulisan program harus dibuat dengan ekstensi (.A51).

\section{Kompilasi Program}

Program yang ditulis menggunakan editor teks kemudian dikompilasi dengan menggunakan program BASCOM AVR. Bila tidak ada pesan kesalahan, proses kompilasi berarti proses kompilasi telah berhasil. Bila ada pesan kesalahan, dapat dicari kesalahan yang terjadi berdasarkan informasi pesan kesalahan tersebut. Hasil dari kompilasi pada gambar diatas kemudian akan berubah menjadi file *HEX. File *HEX inilah yang kemudian dapat diisi ke dalam mikrokontroler melalui downloader.

\section{Pengisian Program}

Perlengkapan yang dibutuhkan dalam pengisian flash mikrokontroler, diantaranya:

- Catu Daya 5 V.

- Rangkaian pengisi Flash EPROM Programmer mode usb.

- PC dengan Sistem Operasi MS Windows 9X/me/NT/2000/Vista/windows 7.

- $\quad$ Perangkat lunak pemrograman.

- Kabel ISP dengan konektor usb untuk komunikasi antara PC dengan rangkaian pengisi Flash EPROM mode usb

Pengisian program yang telah dikompilasi dalam format heksadesimal (hex), diisikan ke dalam Flash EPROM dengan menjalankan perangkat lunak pemrogram yaitu dengan software codevision avr.

Urutan cara pengisian program ke dalam Flash EPROM adalah sebagai berikut :

- Pasang IC pada soket yang telah ditentukan pada rangkaian pengisi Flash EPROM Programmer mode usb

- Pastikan kabel ISP usb antara PC dengan rangkaian programmer telah terpasang.

- Berikan catu tegangan DC $5 \mathrm{~V}$ ke rangkaian pengisi Flash EPROM Programmer mode usb.

- Jalankan perangkat lunak pemrograman.

\section{PENGUJIAN PROGRAM \\ Tujuan Pengujian}

Pengujian dan pengukuran rangkaian pemrograman sistem pengamanan rumah otomatis yang terhubung dengan telepon seluler berbasis mikrokontroler atmega 8 dan atmega 162 sebagai media informasi berbasis mikrokontroler bertujuan untuk mendapatkan data-data yang benar pada titiktitik pengukuran dari alat yang telah dibuat sehingga mempermudah menganalisis sistem dan memperbaiki kerusakan yang mungkin terjadi pada saat sistem bekerja. Langkah pertama dalam percobaan dan pengukuran alat adalah menyiapkan seluruh peralatan yang dibutuhkan untuk mencoba dan mengukur. Untuk mendapatkan data yang benar dan lengkap pada saat pengukuran dibutuhkan ketelitian dan pengukuran berulangulang.

\section{Peralatan Yang Digunakan}

Dalam pengujian ini dilakukan dengan menggunakan peralatan sebagai berikut :

- Rangkaian downloader.

- Software Codevision avr.

- $\quad$ Software BASCOM AVR.

- Rangkaian usb downloader. 
- Rangkaian sistem minimum mikrokontroler ATMega8.

- Rangkaian sistem minimum mikrokontroler ATMega162.

\section{Langkah - Langkah Pengujian}

Langkah-langkah yang dilakukan dalam pengujian pemrograman ini adalah sebagai berikut :

- Mempersiapkan data pemrograman pada software BASCOM AVR.

- Mempersiapkan software codevision avr dan downloader untuk memasukan program ke dalam mikrokontroler.

- Melakukan pengujian pemrograman.

- 4. Menganalisa hasil pengujian berdasarkan percobaan dalam perubahan program pada mikrokontroler.

Pengujian ini dilakukan secara urut dan bertahap pada semua bagian dengan memulainya dari awal yang paling sederhana dengan tujuan menghindari kesalahan sejak awal.

\section{Pengujian Program}

Pengujian ini dilakukan pada program untuk mengetahui apakah jika sebuah program dapat diubah dan berjalan sesuai dengan yang diinginkan serta tidak terjadi sebuah kesalahan atau error. Untuk pemrograman ini dilakukan pengujian yaitu dengan mengganti nama lampu yang ke 6 pada pengontrolan lampu apakah jika diubah penamaannya terjadi sebuah kesalahan atau tidak. Disini lampu yang ke 6 dicoba untuk diubah penamaannya menjadi "teras" di dalam pemrograman

\section{PENUTUP}

\section{Kesimpulan}

Berikut ini kesimpulan-kesimpulan yang didapatkan selama pembuatan tugas akhir ini.

- Pemrograman untuk Sensor PIR dapat berjalan apabila menangkap gelombang inframerah pasif yang dipancarkan oleh tubuh manusia dengan hasil pengujian deteksi jarak sejauh 3 meter yang ditandai dengan jeda waktu 9 detik Buzzer dan lampu indicator yang menyala serta memberikan informasi sms peringatan.

- Pemrograman untuk Sensor Gas dapat berjalan apabila mendeteksi adanya perubahan suhu dalam ruangan dengan hasil pengujian setting suhu awal pada sensor $50^{\circ} \mathrm{C}$ pada tampilan LCD tetera suhu sebesar $68^{\circ} \mathrm{C}$ dengan jeda waktu 8 detik Buzzer dan lampu indicator menyala serta memberikan informasi sms peringatan.

- Pemrograman untuk Sensor Gas dapat berjalan apabila mendeteksi adanya kebocoran Gas LPG dengan hasil pengujian dengan jarak 4cm dengan jeda waktu 2 detik Buzzer dan lampu indicator menyala serta memberikan informasi sms peringatan.

- Pemrograman untuk pengontrolan lampu dapat berjalan apabila format sms yang dikirim dari Hp ke modem benar dan sesuai dengan format yang telah di program pada mikrokontroler. Untuk pengontrolan lampu hanya dapat dilakukan dengan 3 nomor telepon seluler yang telah terprogram pada mikrokontroler, yaitu :

o 085740013289

o 08994403923

o 085640021497

\section{DAFTAR PUSTAKA}

1. Andrianto, Heri. 2008. Pemrograman Mikrokontroler AVR ATMEGA 16 Menggunakan Bahasa C (CodeVisionAVR). Informatika: Bandung

2. Bejo, Agus. 2008. C \& AVR. Graha Ilmu: Yogyakarta

3. Heryanto, Ary \& Adi, Wisnu. 2008. Pemograman Bahasa C untuk Mikrokontroler ATMEGA8535. ANDI: Yogyakarta

4. Malvino, A.P.. 1996. Prinsip-prinsip Elektronika (terjemahan Hanapi Gunawan). Erlangga: Jakarta

5. Nourbakhsh, Illah R.. 2000. Property Mapping: asimple technique for mobile robot programming. proceedings of AAAI 2000.

6. Petruzella, Frank D. Elektronik Industri. Diterjemahkan oleh: Sumanto. Andi: Yogyakarta.

7. Turbian, K. 1973. A Manual for Writers of Term Papers, Theses and Dissertations. $4^{\text {th }}$. Ed. The University of Chicago Press. Chicago.

8. Wardhana, Lingga. 2006. Mikrokontroler AVR seri ATMEGA Simulasi, Hardware, dan Aplikasi. Andi: Yogyakarta 